Tropical Journal of Pharmaceutical Research January 2020; 19 (1): 101-106

ISSN: $1596-5996$ (print); 1596-9827 (electronic)

(c) Pharmacotherapy Group, Faculty of Pharmacy, University of Benin, Benin City, 300001 Nigeria.

Available online at http://www.tjpr.org

Original Research Article

http://dx.doi.org/10.4314/tjpr.v19i1.16

\title{
Anti-glioma effect of 7-H-pyrrolo [2,3-di]pyrimidine derivative via induction of cell death
}

\author{
Jie Wang ${ }^{1}$, Xiang Peng ${ }^{2}$, Chengan $\mathrm{Cao}^{2}$, Yan Zhao ${ }^{2}$, Xing Xia ${ }^{2 \star}$ \\ ${ }^{1}$ Department of General Surgery, ${ }^{2}$ Department of Neurosurgery, Wuhan Fourth Hospital, Puai Hospital, Tongji Medical College, \\ Huazhong University of Science and Technology, Wuhan 430000, China
}

*For correspondence: Email: AnibalFrancovpg@yahoo.com; Tel: 0086-027-68831606

Sent for review: 27 June 2019

Revised accepted: 18 December 2019

\begin{abstract}
Purpose: To investigate the effect of 7-H-pyrrolo[2,3-di]pyrimidine derivative (7-HPPD) on glioma cell growth.

Methods: Cell viability was measured by 3-(4,5-dimethylthiazol-2-yl)-2,5-diphenyl tetrazolium bromide (MTT) assay, while apoptosis was assessed in Hoechst 33342 stained cells using flow cytometry. Changes in cell morphology were assessed by scanning electron microscopy (SEM).

Results: Glioma cell viability showed a concentration-dependent decrease on exposure to 7-HPPD for $72 h(p<0.05)$. The viabilities of C6, U251 and U87 cells were reduced by 24, 28 and $31 \%$, respectively, following treatment with $20 \mu M$ 7-HPPD. Exposure to various concentrations of 7-HPPD resulted in a marked decrease in BrdU LI and cAMP levels in C6, U251 and U87 glioma cells $(p<0.05)$. Moreover, 7-HPPD induced apoptosis in U251 and U87 cell cultures, as was evident in the condensation of chromatin material, presence of apoptotic bodies and intense blue fluorescence. Treatment of U251 cells with 7-HPPD for $72 \mathrm{~h}$ led to a significant increase in the proportion of cells in G0/G1 phase, and significant decrease in percentage of cells in G2/M and S phases. The population of rounded cells showed a significant rise with increase in 7-HPPD concentration from 10 to $20 \mu M$ ( $p<$ 0.05).

Conclusion: 7-HPPD inhibits growth and proliferation of glioma cells by inducing apoptosis. Therefore, it has a potential for application in glioma chemotherapy.
\end{abstract}

Keywords: Glioma, Fluorescence, Metastasis, Apoptosis, Infiltration

This is an Open Access article that uses a fund-ing model which does not charge readers or their institutions for access and distributed under the terms of the Creative Commons Attribution License (http://creativecommons.org/licenses/by/4.0) and the Budapest Open Access Initiative (http://www.budapestopenaccessinitiative.org/read), which permit unrestricted use, distribution, and reproduction in any medium, provided the original work is properly credited.

Tropical Journal of Pharmaceutical Research is indexed by Science Citation Index (SciSearch), Scopus, International Pharmaceutical Abstract, Chemical Abstracts, Embase, Index Copernicus, EBSCO, African Index Medicus, JournalSeek, Journal Citation Reports/Science Edition, Directory of Open Access Journals (DOAJ), African Journal Online, Bioline International, Open-J-Gate and Pharmacy Abstracts

\section{INTRODUCTION}

Glioma is among the most commonly detected intracranial malignant tumors worldwide, and it accounts for more than half of the diagnosed intracranial tumors [1]. According to World Health Organization (WHO), gliomas are categorised into four grades: I, II, III and IV [2]. Grades I and
II are known as low-grade gliomas, whereas grades III and IV are classified as high-grade gliomas [2]. Glioma-associated mortality and disability are very high because of tumor metastasis and frequent tumor relapse.

The current treatment strategy for glioma involves surgery. However, because of deep infiltration, it is difficult to remove the tumor tissue 
completely. Moreover, in most glioma patients, relapse has been observed after surgery [ $\underline{3}$ ]. The glioma treatment strategies have many challenges such as development of resistance to drugs and inability of the drugs to cross bloodbrain barrier [4]. It has been observed that gliomas do not undergo metastasis but infiltrate into the local tissues, leading to the poor prognosis [5]. The currently-used chemotherapeutic agents and surgical methods for glioma treatment are not satisfactory. Therefore, there is need for development of novel therapeutic compounds.

Apoptosis, a highly regulated mechanism for elimination of undesired cells from body is controlled by several genes [6]. It is the vital process for regulation of cancer cell growth, and is explored usually for the development of various anti-cancer treatments [6]. There are several signalling pathways involved in the process of apoptosis, including activation of cysteine proteases and caspases [7]. Activation of the caspases during initial stage of apoptosis leads to death of cancer cells [8].

Natural products are great treasure of compounds for identification of therapeutic principles for glioma [9-11]. Indeed, several compounds have been reported as promising agents for inhibition of glioma growth, and are currently under clinical trials [9-11]. In the present study, the effect of 7-H-pyrrolo[2,3-d]pyrimidine derivative (7-HPPD) on glioma cell growth was investigated.

\section{EXPERIMENTAL}

\section{Cell line and culture}

The C6, U251 and U87cell lines were obtained from the Chinese Academy of Sciences (Shanghai, China). The cells were cultured in Dulbecco's modified Eagle's medium-F12 (DMEM-F12) containing $12 \%$ foetal calf serum and antibiotics i.e. penicillin (100 $\mathrm{U} / \mathrm{mL})$ and streptomycin $(100 \mu \mathrm{g} / \mathrm{mL})$. The cells were cultured at $37^{\circ} \mathrm{C}$ in a $5 \% \mathrm{CO}_{2}$ atmosphere in an incubator.

\section{Cell viability assay}

The viabilities of C6, U251 and U87 cells following $72 \mathrm{~h}$ of incubation with 2, 4, 6, 8, 10, 12 and $20 \mu \mathrm{M}$ 7-HPPD were assessed with MTT assay. The cells were seeded in 96-well plates at a concentration of $1.5 \times 10^{5} \mathrm{cells} / \mathrm{well}$, and cultured for $24 \mathrm{~h}$. Thereafter, the cells were incubated in medium containing 2, 4, 6, 8, 10, 12 or $20 \mu \mathrm{M}$ of 7 -HPPD for $72 \mathrm{~h}$, after which MTT solution added to each well of the plate, followed by incubation of the cells for $4 \mathrm{~h}$. Then, the medium was removed and DMSO was added to dissolve the solid formazan crystals formed. The absorbance of each plate was read at $495 \mathrm{~nm}$ in a microplate reader.

\section{Bromodeoxyuridine (BrdU) labelling analysis}

The C6, U251 and U87 cells were plated in 24-well plates at a density of $2 \times 10^{5}$ cells per well. Following 24-y culture, the cells were exposed to 7-HPPD at concentrations of 2, 4, 6, $8,10,12$ and $20 \mu \mathrm{M}$ for $72 \mathrm{~h}$. The cells were then washed, placed in cover slips and treated with $0.5 \% \quad \mathrm{H}_{2} \mathrm{O}_{2}$ (alcoholic solution). Following PBS washing, the cells were incubated with BrdU antibody (dilution 1:100; catalog no. ab152095; Abcam, Cambridge, UK) at $4{ }^{\circ} \mathrm{C}$. Then, the coverslips were washed with PBS, followed by incubation for $1 \mathrm{~h}$ with secondary antibody $(1: 5,000)$ at room temperature.

\section{Assessment of apoptosis}

U251 and U87 cells seeded 96-well plates at a density of $1.5 \times 10^{6}$ cells/well were exposed to 7 HPPD at concentrations of 10,12 and $20 \mu \mathrm{M}$ for $72 \mathrm{~h}$. Then, the cells were washed three times with PBS, and fixed with paraformaldehyde (4\%) at room temperature for $15 \mathrm{~min}$. The cells were then subjected to staining with Hoechst 33342 $(10 \mu \mathrm{g} / \mathrm{mL})$ at $37^{\circ} \mathrm{C}$ for $20 \mathrm{~min}$, after which the 7 HPPD-induced morphological changes were examined under a fluorescence microscope (Olympus Corporation).

\section{Cell cycle analysis}

The U251 and U87 cells were put into $10-\mathrm{cm}$ culture dishes at a density $1.5 \times 10^{6}$ cells/dish and exposed to 7-HPPD at concentrations of 10, 12 and $20 \mu \mathrm{M}$ for $72 \mathrm{~h}$. After $72 \mathrm{~h}$ of treatment, the cells were harvested, fixed in $70 \%$ ethyl alcohol at $-2^{\circ} \mathrm{C}$ and subsequently washed with PBS. Then, they were stained with $5 \% \mathrm{PI}$ solution in accordance with the manufacturer's instructions. Analysis of apoptosis was done using FACSCalibur flow cytometer connected to Cell Quest software Pro (5.1 version; BD Biosciences, Franklin Lakes, NJ, USA). Data analysis was performed using ModFit LT software package (version 2.0; Verity Software House, Inc., Topsham, ME, USA).

\section{Determination of cyclic 3',5'-monophopshate (cAMP) level}

The C6, U251 and U87 cells were exposed to 8 , 10, 12 and $20 \mu \mathrm{M} 7$-HPPD for $72 \mathrm{~h}$ at a density 
of $2 \times 10^{5}$ cells/well. Following 7-HPPD exposure, the cells were washed three times with PBS, and then treated with radioimmunoprecipitation lysis buffer. The cell lysate was centrifuged at $12000 \mathrm{~g}$ for $20 \mathrm{~min}$, and the supernatant was subsequently mixed with $0.1 \mathrm{~N} \mathrm{HCl}$. The level of cAMP in the supernatant sample was determined using immunoassay. The cAMP level was determined by treating the supernatant overnight with mouse monoclonal antibody against cAMP (dilution 1:100; cat no. 250532; BI Biotech India Pvt., Ltd.) at $4{ }^{\circ} \mathrm{C}$. The supernatant was then incubated with NorthernLights ${ }^{\mathrm{TM}} 557$ conjugated anti-mouse immunoglobulin G secondary antibodies (cat. no. NL007, 1:5,000; BI Biotech India Pvt Ltd) at room temperature for $2 \mathrm{~h}$.

\section{Determination of cell morphology}

The U251 cells were exposed to 10,12 and 20 $\mu \mathrm{M} 7$-HPPD for $72 \mathrm{~h}$ in 24-well culture plates at a density of $2 \times 10^{5}$ cells per well. After incubation, the cells were fixed for $1 \mathrm{~h}$, and then again for 70 $\mathrm{h}$ using glutaraldehyde (2.5\%) and sodium cacodylate buffer at $4^{\circ} \mathrm{C}$. The cells were again fixed for $1.5 \mathrm{~h}$ using osmium tetraoxide at a temperature of $4^{\circ} \mathrm{C}$, after which they were subjected to dehydration with gradient ethanol and amyl acetate. Then, the cells were fixed on gold-palladium alloy coated slides, and the morphological changes were determined using scanning electron microscopy (Jeol-JSM-5200).

\section{Statistical analysis}

The data are expressed as mean \pm SD of triplicate experiments performed independently. Data analysis was carried out using one-way analysis of variance (ANOVA) and the Bonferroni post-test. Differences were considered statistically significant at $p<0.05$.

\section{RESULTS}

\section{7-HPPD inhibited C6, U251 and U87 glioma cell growth}

Figure 1 shows the effect of 7-HPPD on growth of C6, U251 and U87 cell lines at $72 \mathrm{~h}$, as measured using MTT assay. Concentrationbased decreases in viabilities of all the three tested cell lines were observed on exposure to 2 , 4, 6, 8, 10, 12and $20 \mu \mathrm{M}$ 7-HPPD for $72 \mathrm{~h}$. The viability of C6 cell was reduced to $91,86,73,57$, 45,32 and $24 \%$, on treatment with 2, 4, 6, 8, 10, 12 and $20 \mu \mathrm{M} 7-H P P D$, respectively. Treatment with 2, 4, 6, 8, 10, 12 and $20 \mu \mathrm{M}$ 7-HPPD reduced the viability of U251 cells to 93, 84, 68, $52,47,35$ and $28 \%$, respectively. Similarly, in U87 cells, viability was reduced to $95,83,75,66$,
57,44 and $31 \%$, on treatment with $2,4,6,8,10$, 12 and $20 \mu \mathrm{M}$ 7-HPPD, respectively.

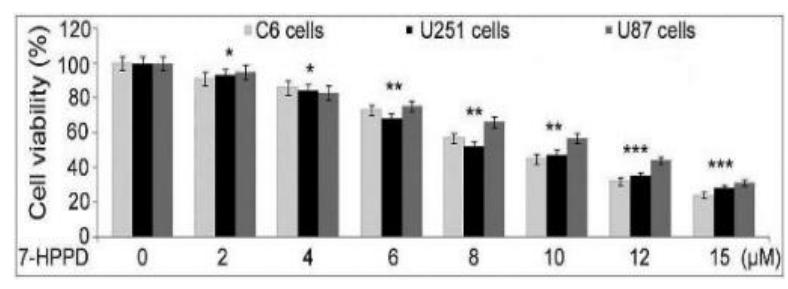

Figure 1: Effect of 7-HPPD on C6, U251 and U87 cell viability. The three cell lines were exposed for $72 \mathrm{~h}$ to $5,10,15,20,25,30$ and $50 \mu \mathrm{M}$ 7-HPPD, and cell viability was determined using MTT assay; * $p<0.05$, ${ }^{* *} p<0.002,{ }^{* * *} p<0.001$, versus untreated cells

\section{7-HPPD decreased BrdU-labeling index in glioma cells}

The C6, U251 and U87 cells were treated with 2, 4, 6, 8, 10, 12 and $20 \mu \mathrm{M}$ 7-HPPD (Figure 2). The treatment decreased BrdU-LI labelling in concentration-dependent fashion. The BrdU-LI labelling was reduced to 22, 23 and $29 \%$ in C6, U251 and U87 cells, respectively, on exposure to $20 \mu \mathrm{M}$ 7-HPPD.

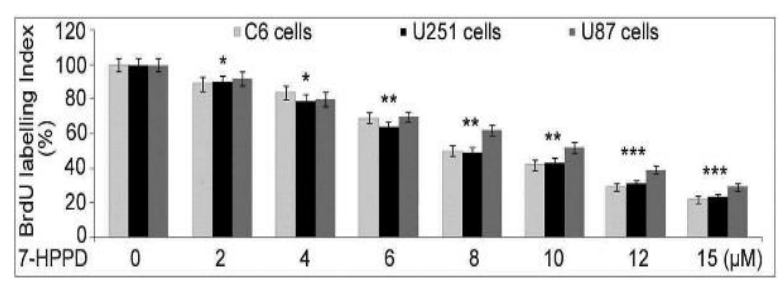

Figure 2: Effect of 7-HPPD on BrdU-LI in glioma cells. The 7-HPPD exposure of C6, U251 and U87 cells was followed by analysis of BrdU uptake at $72 \mathrm{~h}$. The labelling index was measured three times independently; $\quad{ }^{*} p<0.05, \quad{ }^{* *} p<0.002, \quad{ }^{* * *} p<0.001$, relative to untreated cells

\section{7-HPPD suppressed cAMP in C6, U251 and U87 glioma cells}

The cAMP level in glioma cells was determined after $72 \mathrm{~h}$ of exposure to 8, 10, 12 and $20 \mu \mathrm{M} 7$ HPPD (Figure 3). Exposure of C6, U251 and U87 cells to7-HPPD significantly $(p<0.05)$ decreased cAMP level in a concentration-dependent manner. Compared to the untreated cells, 7HPPD treatment significantly decreased cAMP level in all the three cell lines from $8 \mu \mathrm{M}$.

\section{7-HPPD produced apoptosis in U251 and U87 cells}

The U251 and U87 cells were exposed to 7HPPD at concentrations of 8, 10, 12 and $20 \mu \mathrm{M}$ for $72 \mathrm{~h}$, after which apoptosis was analysed using Hoechst 33342 staining (Figure 4). 
Apoptosis induction in U251 and U87 cell cultures on exposure to 7-HPPD was evident from condensation of chromatin material, presence of apoptotic bodies and intense blue fluorescence. A significant increase in the population of apoptotic cells was observed in U251 and U87 cell cultures on exposure to 7HPPD, when compared to the control cells.
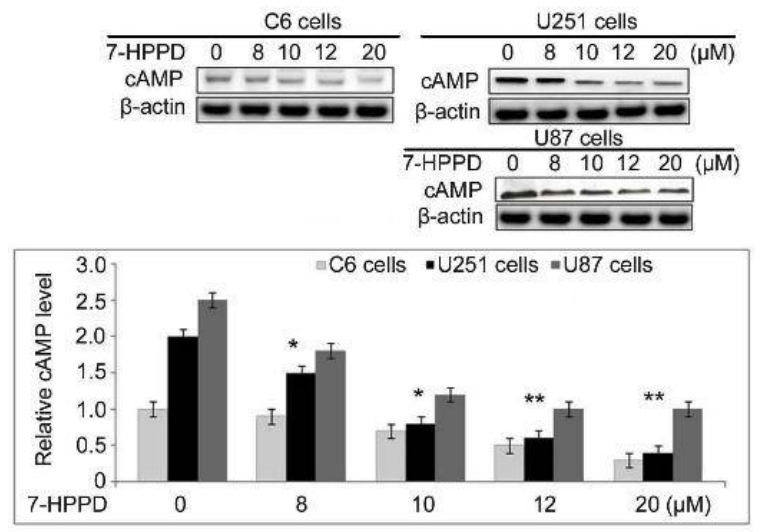

Figure 3: Suppression of cAMP level by 7-HPPD. In C6, U251 and U87 cell cultures, cAMP level was assayed at $72 \mathrm{~h}$ of exposure to indicated concentrations of 7-HPPD. The experiments were performed three times independently; ${ }^{*} p<0.05$, ${ }^{\star *} p<0.001$, versus untreated cells
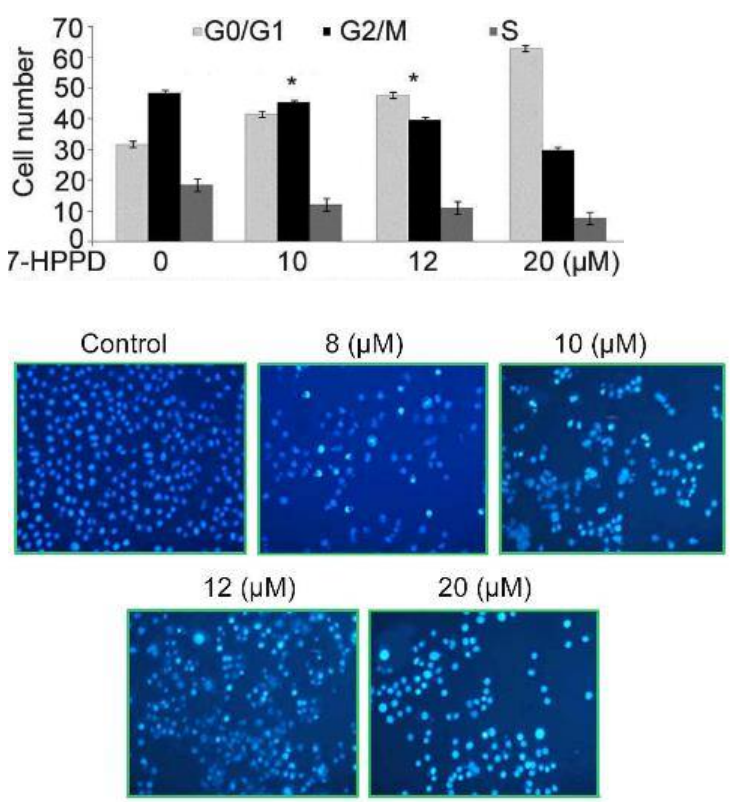

Figure 4: Effect of 7-HPPD on glioma cell apoptosis. The U251 and U87 cells were treated with 8, 10, 12 and $20 \mu \mathrm{M}$ 7-HPPD for $72 \mathrm{~h}$. Fluorescence microscopy was used for analysis of cell apoptosis. Magnification: x250

\section{7-HPPD caused G0/G1 phase cell cycle arrest in U251 cells}

Treatment of U251 cells with 10,12 and $20 \mu \mathrm{M}$
7-HPPD for $72 \mathrm{~h}$ led to significant increases in the proportion of cells in G0/G1 phase (Figure 5). The percentage of cells in $\mathrm{G} 2 / \mathrm{M}$ and $S$ phases decreased significantly on treatment with 7HPPD, relative to the control cells. Exposure of U251 cells to 10,12 and $20 \mu \mathrm{M}$ 7-HPPD increased G0/G1 phase cell population to 41.54 , 47.67 and $62.88 \%$, respectively. In G2/M phase, cell proportion was decreased to $45.08,39.44$ and $29.65 \%$, respectively on exposure to 10,12 and $20 \mu \mathrm{M}$ of 7 -HPPD, when compared to $48.23 \%$ in untreated cells. In S phase, cell percentage was decreased to $11.98,10.89$ and $7.53 \%$, respectively on exposure to 10,12 and $20 \mu \mathrm{M}$ 7-HPPD.

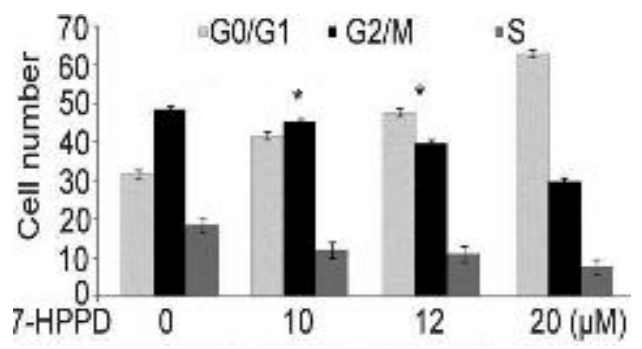

Figure 5: 7-HPPD induced cell cycle arrest in U251 cells. The 7-HPPD-treated glioma cells were analysed for cell cycle distribution at $72 \mathrm{~h}$ with flow cytometry. The cells were exposed to 10, 12 and $20 \mu \mathrm{M}$ 7-HPPD; ${ }^{*} p<0.05,{ }^{* *} p<0.002,{ }^{* *} p<0.001$ versus untreated cells

\section{7-HPPD changes morphological of U251 cells}

Treatment of U251 cells with $8,10,12$ and 20 $\mu \mathrm{M}$ 7-HPPD caused marked changes in cell morphology (Figure 6). There was rounding of cells on treatment with 7-HPPD for $72 \mathrm{~h}$. The population of rounded cells showed marked increases with increase in concentration of 7HPPD from 10 to $20 \mu \mathrm{M}$. In contrast, the untreated cells were spindle-shaped and diving at higher rates, as shown through scanning electron microscopy.

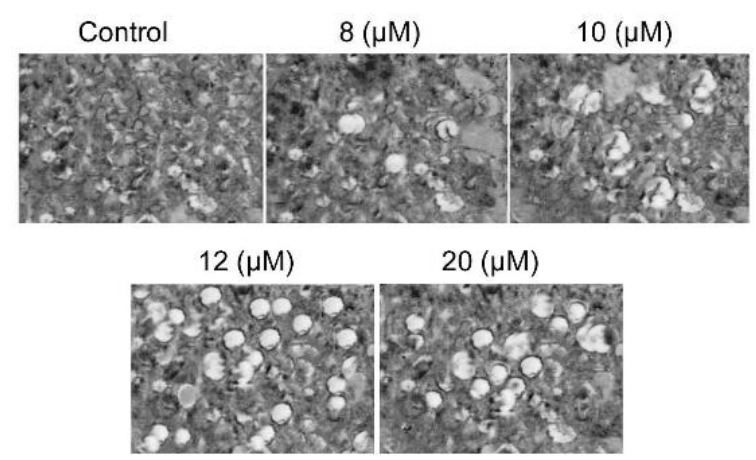

Figure 6: Effect of 7-HPPD on U251 cell morphology. The cells were exposed to 8, 10, 12 and $20 \mu \mathrm{M}$ 7HPPD for $72 \mathrm{~h}$, and changes in morphology were determined using SEM. Images were taken at x750 magnification

Trop J Pharm Res, January 2020; 19(1): 104 


\section{DISCUSSION}

The development of treatment for glioblastoma multiforme is a serious challenge to clinicians throughout the world. Natural product screening has led to the identification of compounds which possess promising glioma-inhibitory potential [12-14]. In the present study, the effect of 7- $\mathrm{H}$ pyrrolo[2,3-di]pyrimidine derivative (7-HPPD) on glioma cell growth was investigated. The study demonstrated that 7-HPPD inhibited growth and proliferation of glioma cells, arrested cell cycle, suppressed cAMP level and led to apoptosis induction. Higher proliferation of C6 glioma cells has been linked to the activation of platelet-derived growth factor receptors (PDGFRs) [15,16].

Studies have revealed that PDGFRs activation causes increase in the level of cAMP in glioma cells [15-18]. The interaction between activated PDGFRs and cellular $\beta$-adrenoreceptors enhances proliferation of the carcinoma cells through up-regulation of cAMP levels $[15,16]$. In the present study, 7-HPPD treatment markedly suppressed the viability of C6, U251 and U87 glioma cell lines. Concentration-based reductions in glioma cell viability was caused by 7-HPPD in C6, U251 and U87 cells. The level of cAMP was decreased significantly in U251 and U87 cells on treatment with 7-HPPD. Compared to the untreated cells, 7-HPPD treatment significantly decreased cAMP level in all the three cell lines.

Apoptosis, a highly regulated mechanism for the removal of unwanted cells from body, is controlled by several genes [6]. It is the vital process for regulation of cancer cell growth, and it is being explored for the development of various anti-cancer treatments [6]. In the present study, the effect of 7-HPPD on apoptosis induction in U251 and U87 cells was analysed flow cytometrically. The results showed that 7HPPD exposure led to significant increases in the proportions of apoptotic cells in U251 and U87 cells. The 7-HPPD exposure also caused marked enhancement of the percentage of cells in $\mathrm{G} 0 / \mathrm{G} 1$ phase, with subsequent reductions in the G2/M and $S$ phases of cell cycle. These findings suggest that 7-HPPD suppresses glioma cell viability through apoptosis and cell cycle arrest.

Generally, apoptosis is due to changes in mitochondrial membrane permeability resulting in activation of the caspases [19-21]. Caspase activation causes formation of membrane projections, rounding of cells, and degeneration of the cell membrane [21]. In the present study, the effect of 7-HPPD on morphology of the glioma cells was determined using scanning electron microscopy. The results showed that 7HPPD treatment led to the development of membrane projections and rounding of U251 in concentration dependent manner.

\section{CONCLUSION}

Treatment with 7-HPPD inhibits the growth and proliferation of glioma cells by inducing apoptosis. Therefore, 7-HPPD is a potential chemotherapeutic agent for glioma.

\section{DECLARATIONS}

\section{Conflict of interest}

No conflict of interest is associated with this work.

\section{Contribution of authors}

We declare that this work was done by the authors named in this article and all liabilities pertaining to claims relating to the content of this article will be borne by the authors. Xing Xia designed the study and wrote the research paper. Jie Wang, Xiang Peng, Chengan Cao and Yan Zhao performed the experimental work, carried out the literature study and compiled the data. Jie Wang and Xiang Peng performed literature survey, analyzed the data and compiled the data. The research article was thoroughly read by all the authors before commination for the consideration of publication.

\section{Open Access}

This is an Open Access article that uses a funding model which does not charge readers or their institutions for access and distributed under the terms of the Creative Commons Attribution License (http://creativecommons.org/licenses/by/ 4.0) and the Budapest Open Access Initiative (http://www.budapestopenaccessinitiative.org/rea d), which permit unrestricted use, distribution, and reproduction in any medium, provided the original work is properly credited.

\section{REFERENCES}

1. Bush NA, Chang SM, Berger MS. Current and future strategies for treatment of glioma. Neurosurg Rev2017; 40:1-14.

2. Hempel JM, Schittenhelm J, Brendle C, Bender B, Bier G, Skardelly M, Tabatabai G, Castaneda VS, Ernemann $U$, Klose $U$. Effect of perfusion on diffusion kurtosis imaging estimates for in vivo assessment of integrated 
2016 WHO glioma grades: A cross-sectional observational study. Clin Neuroradiol2017; 1-11.

3. Feng $X, Y u Y, H e S$, Cheng J, Gong $Y$, Zhang Z, Yang $X$, Xu B, LiU X, Li CY. Dying glioma cells establish a proangiogenic microenvironment through a caspase 3 dependent mechanism. Cancer Lett2017; 385: 12-20.

4. Madsen SJ, Christie C, Hong SJ, Trinidad A, Peng Q, Uzal FA, Hirschberg H. Nanoparticle-loaded macrophage-mediated photothermal therapy: Potential for glioma treatment. Lasers Med Sci2015; 30: 13571365.

5. Maher EA, Furnari FB, Bachoo RM, Rowitch $D H$, Louis $D N$, Cavenee WK, DePinho RA. Malignant glioma: Genetics and biology of a grave matter. Genes Dev 2001; 15: 13111333

6. Hikita H, Kodama T, Shimizu S, Li W, Shigekawa M, Tanaka S, Hosui A, Miyagi T, Tatsumi T, Kanto T. Bak deficiency inhibits liver carcinogenesis: A causal link between apoptosis and carcinogenesis. J Hepatol 2012; 57: 92100.

7. Ahamed M, Akhtar MJ, Siddiqui MA, Ahmad J, Musarrat $J$, Al Khedhairy AA, AlSalhi MS, Alrokayan SA. Oxidative stress mediated apoptosis induced by nickel ferrite nanoparticles in cultured A549 cells. Toxicol 2011; 283: 101108.

8. Zhang S, Li T, Zhang L, Wang X, Dong H, Li L, Fu D, Li $Y$, Zi X, Liu HM. A novel chalcone derivative $S 17$ induces apoptosis through ROS dependent DR5 up regulation in gastric cancer cells. Sci Rep 2017; 7: 9873.

9. Chang SM, Lamborn KR, Malec M, Larson D, Wara W, Sneed $P$, Rabbitt J, Page M, Nicholas MK, Prados MD. Phase II study of temozolomide and thalidomide with radiation therapy for newly diagnosed glioblastoma multiforme. Int J Radiat Oncol Biol Phys 2004; 60: 353 357.

10. Fine $H A$, Wen $P Y$, Maher EA, Viscosi E, Batchelor $T$, Lakhani N, Figg WD, Purow BW, Borkowf CB. Phase II trial of thalidomide and carmustine for patients with recurrent highgrade gliomas. J Clin Oncol 2003; 21: 22992304.
11. Marx GM, Pavlakis N, McCowatt S, Boyle FM, Levi JA, Bell DR, Cook R, Biggs M, Little N, Wheeler HR. Phase II study of thalidomide in the treatment of recurrent glioblastoma multiforme. J Neurooncol 2001; 54: 3138.

12. Buchdunger E, Cioffi CL, Law N, Stover D, Ohno Jones $S$, Druker BJ, Lydon NB. Abl protein tyrosine kinase inhibitor STI571 inhibits in vitro signal transduction mediated by $c$ kit and platelet derived growth factor receptors. J Pharmacol Exp Ther 2000; 295: 139145.

13. Yu C, Krystal G, Dent $P$, Grant S. Flavopiridol potentiates STI571 induced mitochondrial damage and apoptosis in $B C R$ ABL positive human leukemia cells. Clin Cancer Res 2002; 8: 29762984.

14. Uziel O, Fenig E, Nordenberg J, Beery E, Reshef $H$, Sandbank J, Birenbaum $M$, Bakhanashvili $M$, Yerushalmi $R$, Luria $D$, et al. Imatinib mesylate (Gleevec) downregulates telomerase activity and inhibits proliferation in telomerase expressing cell lines. $\mathrm{Br} \mathrm{J}$ Cancer 2005; 92: 18811891.

15. Sokołowska $P$, Nowak JZ. Constitutive activity of betaadrenergic receptors in $\mathrm{C} 6$ glioma cells. Pharmacol Rep 2005; 57: 659663.

16. Grobben B, De Deyn PP, Slegers H. Rat C6 glioma as experimental model system for the study of glioblastoma growth and invasion. Cell Tissue Res 2002; 310: 257 270.

17. Jaiswal BS, Conti M. Calcium regulation of the soluble adenylyl cyclase expressed in mammalian spermatozoa. Proc Natl Acad Sci USA 2003; 100: 1067610681.

18. Baillie GS, Houslay MD. Arrestin times for compartmentalised cAMP signalling and phosphodiesterase 4 enzymes. Curr Opin Cell Biol 2005; 17: 129134.

19. Adams JM, Cory S. The Bcl 2 protein family: Arbiters of cell survival. Science 1998; 281: 13221326.

20. Antonsson B, Martinou JC. The Bcl 2 protein family. Exp Cell Res 2000; 256: 5057.

21. Salvesen GS, Dixit VM. Caspases: Intracellular signaling by proteolysis. Cell 1997; 91: 443444. 